Mid-American Review of Sociology

Russell, Jeffrey Burton

1972 Witchcraft in the Middle Ages. Ithaca: Cornell University Press.

Sprenger, Jacob and Heinrich Kramer

1928 Malleus Maleficarum (1486). Translated with an introduction, bibliography and notes by the Reverend Montague Summers. London: John Rodker.

Summers, Montague

1927 The Geography of Witchcraft. London: Kegan Paul, Trench Trubner \& Co., Ltd.

1956 The History of Witchcraft and Demonology. New York: University Books.

Szasz, Thomas S.

1970 The Manufacture of Madness. New York: Dell.

Weitzman, Lenore J.

1975 "Sex Role Socialization" in Jo Freedman ed., Women: A Feminist Perspective. Palo Alto, Calif.: Mayfield.

Zilboorg, Gregory

1941 A History of Medical Psychology. New York: W.W. Norton and Co.
NOTES AND COMMENTS

\section{SOCIOLOGICAL IMPLICATIONS OF THE HABERMAS-RELATED SECOND GENERATION OF THE FRANKFURT SCHOOL: A BIBLIOGRAPHIC ESSAY}

\section{Richard R. Weiner}

University of North Florida

The tradition of the Critical Theory of Society developed by the Frankfurt.School has been renewed by a second generation. Most prominent among them is JürgenHabermas and his colleagues Karl Otto Apel and Alfred Schmidt. Also of significance are both the dialogues and debates between Habermas and his students: Claus Offe, Oskar Negt and Bernard Willms.

The specific themes argued by the Frankfurt School diverge from their chosen paradigm-Marx's critique of political economy. Fundamentally, Critical Theory radically revised the terms of Marx's analysis, redirecting its focus from the infra-structure to the superstructure, replacing the critique of political economy with the critique of instrumental rationality. They sought to perceive simultaneously the combined effects of constitutive objective-historical conditions of domination and constituting subjective-intentionality of practical reasoning.

For the Frankfurt School, the existing relations of production came to be seen as that form of organization which is technically necessary for a rational society, while all social problems had been made to seem to be questions of technical adjustment. In the Dialectic of Enlightenment Horkheimer and Adorno emphasize the emergent modern conflict between two concepts of reason. Practical reason is grounded in deliberation and dialogue over the conditions of the good life. Instrumental reason is found in the technical control of nature.

In this vein Habermas distinguishes between instrumental and communicative action. In instrumental action we encounter objects the paradigm for which are moving bodies, capable of 
manipulation. In communicative action we encounter objects the paradigm for which are speaking and acting subjects, understandable through symbols.

Habermas' theory of communicative competence or universal pragmatics makes use of a fundamentally hermeneutic critique of systematically distorted messages. Now, in accentuating the mediation of traditions through dialogue, the hermeneutics of Hans-Georg Gadamer has gone beyond the Wittgensteinian notion of the language game by distancing traditions to the point of ineffability, foreclosing the possibility of subjecting them to rational critique. Consequently, Habermas rejects a purely hermeneutic analysis of the Gadamerian sort, but only because it does not critically demystify the distorted and distorting structures of the objective constitutive terms.

For Habermas, we must somehow break free from the disguised authoritarian control of our managed societies by exposing scientism and making real again a public sphere (öfentlichkeit) in which citizens can engage in rational discourse about their needs and can collectively, and with enlightened understanding, decide on their common aims.

For Habermas, the constituting character of practical reasoning describes the intersubjective, ergo, intercommunicable mediation within the public communicative sphere of practical consciousness. Such practical conscious activity confronts us with our "constitutive self-formation of the existing" rules of the game in order to recognize the immanent possibilities objectively present.

Habermas' theory of communicative competence or universal pragmatics (i.e., dialogue constitutive universals) attempts to include intersubjective hermeneutic consciousness and validity claims (Wahrheitsbezug) within a more objectively rationalistic ideal typical analysis. Yet it is an approach which doesn't attempt to achieve objectivity in the sense in which the term is used in the natural sciences (i.e., not as a result of a process of objectivation), nor in the sense of some sort of permanent knowledge. Rather it seeks to appreciate the intersubjective, i.e., intercommunicable, mediation of constituting practical reasoning and its constitutive objective-historical constraints as a "text". It seeks to understand such a text in terms of the grammar of a language game rooted in a set of contextually specific generative rules-rules invoked to legitimate or evaluate some course of action. In constructing this theory, Habermas stresses subsequent sustained and careful concrete empirical research to ascertain the likelihood of alternatively constituted possibilities being realized.

Habermas' theory of communicative competence or universal pragmatics takes its departure from the notion of a smoothly functioning language game which rests on a background consensus. This consensus is conceived as being based on the mutual recognition of various kinds of validity claims which are implied in all speech acts. Habermas' idea of communicative competence is derived from the Austin-Searle tradition of linguistic philosophy. Following Searle, he designates the speech act as the elementary unit of intersubjective, i.e., intercommunicative, mediation within the public sphere of practical consciousness. The speech act is a projection ... not merely a symbol, a word or a sentence. Nor is it a token of a symbol of a word or of a sentence. Rather, the speech act is "the production or issuance of a sentence token under certain conditions."

Habermas argues that a smoothly functioning language game rests on a background consensus formed from the mutual recognition of at least four different types of validity claims (Geltungsansprüche) which are involved in the exchange of speech acts: the claims that the utterance is understandable and that its propositional content is true, and the claims that the speaker is authentic (Wahrhaftig) in uttering it, and that it is right or appropriate(richtig) for him to be performing the speech act which he performs.

Thus, Habermas' redefinition of Critical Theory starts with communicative action in which these implicitly raised validity claims are naively accepted, but focuses in on those emergent situations in which one or more of these validity claims becomes problematical. Such a problematic develops when the background consensus-that is, the accepted framework of opinions and norms-is called into question and the claims which were previously only implicit, now require discursive justification. For Habermas, the validity of problematic truth claims or of 
problematic norms can be redeemed only by entering into a discourse which has the purpose of judging the truth of the problematic opinion or the correctness of the problematic norm (Legitimation-problem).

Such "pratical discourse"-as opposed to a purely theoretical one-involves the supposition by the participants that they are in an "ideal speech situation": that they are discussing under conditions which guarantee that the consensus which is arrived at will be the result of the force of the better argument and not of the constraints on the discussion. Thus, for Habermas, the requirements of the ideal speech situation are such that the conditions for ideal discourse are connected with conditions for an ideal form of social life: one in which autonomy and responsibility are possible as inherent in the structure of social action, that is, a structure of speech.

For Habermas, the critical theorist makes the counter-factual assumption and then asks: what would each member of a society think if he or she was completely aware of the situation, free and able to verbalize the occluded aspects of social life, and could ask whether his or her empirical interests were or were not universalizable? From this counter-factual question, it becomes possible to show both the functional necessity for the system to legitimate itself ideologically, and at the same time, to indicate the possible forms of critique of that ideology.

To avoid the relativism and the contingency of empirical social referents which could change at any time, and to avoid the ahistoricality of a fixed notion of truth outside the sphere of human relations, Habermas moved beyond the position of Knowledge and Human Interests and Theory and Practice where the question of the validity of social norms and the truth of metatheoretical statements is concerned.

In his recent attempts at a theory of social evolution ("Towards a Reconstruction of Historical Materialism"), Habermas continues in his quest to make possible a notion of collective practical reasoning.(or "Social Praxis") which is not contingent, but rather truth-oriented and open to discursive questioning. He differentiates tasks of critical theory from the domain of a theory of social evolution: the Konstitution frage from the Warhrheitsbezug.
Thus, critical theory is understood as referring to the constitution of the life-world, that is, it makes up the categorical meanings which provide the content of a statement. A theory of social evolution refers to the validity-claim constituted by the intersubjective element in the performative aspect of the speech act. The first focuses on the subjective/objective frame of reference, whereas the second fastens on the intersubjective and the mediate in the discourse of all potential participants. The former is bound to a monological action context, while the latter is concerned with the reconstruction of universal and anonymous systems of rates within the context of a discourse removed from practical imperatives. The "self-reflexion" achieved by the former has practical consequences, whereas the attempt to ground Habermas' dialogue-constitutive universals in a theory of social evolution aims at the transcendental: a transcendental critique of language to reveal the transcendental foundation of species-activity.

Habermas' theory of communicative competence/universal pragmatics describes the grammar of a language game as being rooted in a set of contextually specific generative rules: the public sphere and its social rules. In such a Kommunicationsgemeinschaft model speakers are treated as if they followed rules in confronting and negotiating particular action situations. Location of and knowledge of such rules constitute them as competent speakers.

The intention of Habermas' theoretical endeavors is to distinguish an "accepted consensus" or legitimation ("Hegemony") from the "rational consensus" of the ideal speech situation ("Truth"). His purpose-in line with the tradition of Critical Theory-is to renew the classical quest for that ideal form of life where objective social institutions and practices can exist that permit free, responsible and non-ideological social discourse in which we can collectively constitute community: the Kommunicationsgemeinschaft.

Habermas' endeavors assume: (1) that normative rules cannot be divorced from the interactional settings in which meanings are attributed to objects and events; (2) that a rule-governed structure transcends the actual performance of speech acts; (3) that interpretation is required to recognize the abstract rule which fits 
a particular performance; and (4) that every attempt to describe the structure of language relies on practical reasoning.

The theorizing of Habermas points sociologists necessarily to many of the conceptual tools developed by the more interpretive modes of sociology, specifically those bent on discovering the fundamental normative ordering in the performance of speech acts. There is an insistance here on understanding human action with reference to the interpersonally shared meaning that action has for agents, particularly the interpretive procedures (e.g., Cicourel), accounting procedures (e.g., Scott and Lyman) and common frames of reference (belief systems, ideologies, symbolically mediated understandings, moral paradigms, and traditions) interpersonally employed. This emphasis, however, is not a license for unbridled subjectivism. One of the dominant themes in analytic philosophy has been that language and human action are rooted in (1) interpersonal, that is, intersubjective contexts of communication, and (2) intersubjective practices and forms of life (cf. Wittgenstein, Philosophical Investigations, Paragraph 23).

The hermeneutic sociological theorizing suggested by Habermas and Apel is directed toward understanding interaction: the participation of actors in an intersubjective "form of life". By "form of life" we denote (1) "a matrix of human activities with point, purpose and regularity", and (2) "what people do, as they comment upon, reflect upon and formulate what they perform" (Clegg, p. 36). These activities and utterances are manifested in some logic-in-use, a public language.

We are led to investigate a public language rooted in institutions and practices, common meanings, and collective identities. Similarly we are led to the study of intersubjective capabilities: predispositions, biographies, organizable resources, degree of communicative competency, and the strategy of practical reasoning.

In Habermas' communications theory the notion of the "negotiated creativeness" of practical reasoning underlines the actors' reliance on normative rules for finding and justifying the meaning of events as socially organized. The learning and application of such general rules or norms and their long term storage require interpretive and accounting procedures for recognizing and standardizing the relevance of actual, changing action-situations, orienting the actor to possible courses of action. The interpretive procedures orient us to the normal "forms. life" that constitute our social reality; they provide us with developmentally changing sense of social structures, enabling a to assign meaning or relevance to an environment of objects of reference. In this sense it retains a Weberian tone in its continued "indexicality", i.e., its reference to objects described in contextual terms and bound to their occasioned use. Indexicality implies knowledge that is in some way ordered or organized according to some rationale.

Cicourel $(1973: 44,76-81,107-111)$ refers to the rules underlying our performance of speech acts as "surface rules" (surface structure). However, "indexical" concerns with the underlying rules that both structure speech and "index" cognition and thought require the attribution of meaning beyond the surface form. They point to that which is labelled the "depth structure" or grammar of a particular language .... and beyond to the dominant principle(s) [what Habermas refers to as the "fundamental organizing constitutive principle"] that provide the matrices or parameters to some public language.

For Habermas "practical activity" is oriented to some "order", or "structure" with a grammatical system of "organizing" rules. Legitimations or accounts shape the way in which a subject interprets his experiences and the social regularities he finds; they presuppose cognitive construction of the self, of some collectivity, and of the environimental field of action. These cognitive constructs provide "rationales" for the self-reflexive consciousness. They enable the actor to discover "good" reasons for accounting for some action as legitimate or not.

Ultimately, Habermas' theorizing remains-beyond the concerns of more purely interpretive modes of sociology-linked to the original paradigm of the Frankfurt School, the Marxian critique of political economy. For Habermas never fails to assume that certain material conditions will be necessary for the telos of the discursively achieved consensus to be concretely realized and objectively constituted. 
Class relations are "structurally" generated by "asymmetries" in the material reproduction of modes of social existence (Weber's "life chances"). Unlike the notion of an intersubjective life-world, that of structure exists "out of time and space", it only exists as "the reproduced conduct of situated actors with definite intentions and interests" (Giddens:127). Still in The German Ideology Marx and Engels noted that

This mode of reproduction must not be viewed simply as reproduction of the physical existence of individuals. Rather it is a definite form of their activity, a definite way of expressing their life, a definite mode of life. As individuals express their life, so they are (cited in Clegg:40).

It is in the realm of the intersubjective life-world that we recognize the presence of others, communicate intentions, and negotiate results. The objective and normative reproduction of practices is referred to abstractly as "structuration": a dynamic process whereby grammatical rules "systematically" generate the totality of speech acts which is the spoken language (Giddens:121-122). (Here we approximate the distinction between: (1) la parole/speech acts; (2) le langage/practices, a "tongue"; and (3) la langue/language, a code with a structure of grammatical rules [Saussure:23-31; cf. Jakobson]).

Historically, language exists as a systematically integrated structure of rules (norms) which in the contingent empirical realm of appearances approximates a structure of dominancy. A "structure of dominancy" in Weber's theorizing (Wever:31) represents an order of signification that underlies the surface appearance of power, interaction and role-performance. Such a structure of dominancy is experienced in terms of rules to which speech actors orient their conduct. These rules are a public phenomenon displayed in the ways in which people use language.

The concept of "rule" links the structural notions explicit in "domination" to the actions of ordinary people. Following both Weber and Simmel we can distinguish between the "form" of domination and its "content", i.e., systems of rules providing different "orders" to which people orient their speech acts.
These systems of rules make up that which Habermas refers to as the "background" or "accepted" consensus: what the ethnomethodologists label the "background assumptions" of everyday life (Giddens:123-24,127). They provide the contexts of meaning with which to understand attempted communication (Habermas' practical cognitive interest), the operation of control (Habermas' technical cognitive interest), or moral relations (Habermas' emancipatory cognitive interest).

The emergent theoretical corpus of Habermas and Apel, as well as recent developments in interpretive sociology, can be understood as yielding the following summary analytical framework (itself derived from Habermas).

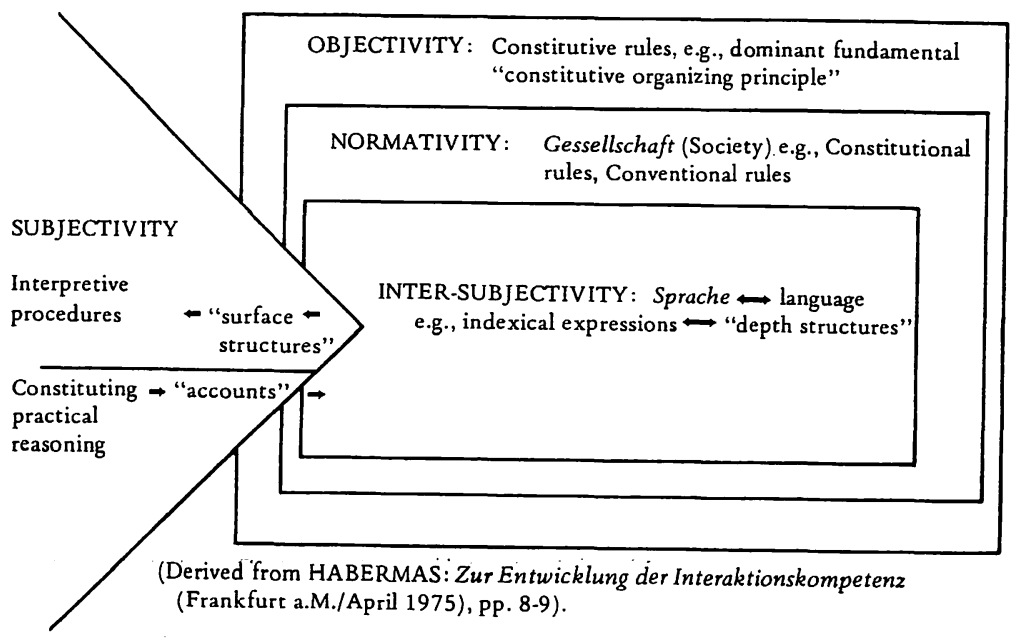


The critical reflections of the Frankfurt School tend to go beyond the language of convention and seek to trace back all "mediations" (e.g., meanings, values, institutions) to the human operations that constitute them. In The Concept of Nature in Marx another second generation Frankfurter Schüler, Alfred Schmidt, demonstrates how Marx's concern is with the socially mediated character of nature and the historical condition of its change, rather than any genetic primacy of materialist being. The relation between individual and nature, individual and mankind, and individual and society is appreciated as an inherently "mediated" one, i.e., articulated, conditioned, and modified by man's cognitive and social authority. As finite and temporally determined, men and women are mediating subjects, a part of the reality of things mediated through them, and know only a socially mediated reality.

Schmidt concludes that one must ultimately return to the concept of practice (practical reasoning) to appreciate what Marx meant by dialectical/historical materialism. "It is only the process of knowing nature which can be dialectical not nature itself." (195)

When understood critically Marxist materialism does not attempt to assert anything of the material world in abstraction from the practical-intellectual forms of its "appropriation" by a given society (10).

The developing political sociology of Claus Offe further continues Critical Theory's attempt to confront that which is missing in Marx's analysis of institutions. Offe's approach focuses on "the action space of the capitalist institutions of political governance" in order to discern any distinct structural limitations, i.e., any internal rule-structures of specificity. He conceptualizes the institutionalized context of class domination as a regulating system with specific "selective mechanisms". These mechanisms can be visualized as a "filter system" that systematically selects specific outcomes out of an infinite number of possibilities. They are coordinative and repressive.
One selective mechanism has to extract a general class interest from particular interests of specific capitals, which themselves may be rather limited, competing and short-sighted. This formulation of a general class interest for the whole society may be directed in part against some particular capital interests (Sardie-Bierman, et al., 62).

And another "selective mechanism"

has to oppress anti-capitalist interests and conflicts. It also has to provide possibilities for the concrete realization of the general class interest (Ibid).

These two selective mechanisms are concealed by a third kind: that of the ideological hegemony of a dominant political paradigm's interpretive schemes and tacit understanding. That ideological hegemony penetrates thought and action, and is related to the way in which action is legitimized. The "class" nature of the institutions of political governance is denied, and the phenomena Marx refers to as "false consciousness" is molded.

The function of selective mechanisms embedded within the institutions of political governance is a legitimizing one. They operate to realize the class interests of the hegemonic power bloc "under the name of the benefit to society as a whole." However they do so in a manner geared

to avoid the danger that an openly practiced class nature of the State might lead to a polarization of class conflicts (Ibid. 63).

In Offe's political sociology the state apparatus of decision-making and administration is conceived as operating within an institutional environment of "rules of the game", "boundaries", "limits", "parameters", and "basic logics". That institutional context is in turn structured by the underlying mode of production of organized class society, and its operating principles, exchange value and the accumulation of capital. The central problematic, then, that Offe's approach raises is that of deciphering the internal structures of the political scene which 
guarantee the conversion of the interests of the process of surplus value creation into public policy.

Habermas' [and Abedroth's] notion of the "public sphere" should be understood as the categorical mediation between a developing material production and the cultural organization of human experience (i.e., norms and institutions) during the process of the constitution of social experience. Ideally, the bourgeois public sphere (and its truth) contained the potential for the universalization of a practical critique of a system of "rationality". Yet increasingly, Habermas notes in Legitimation Crisis (70)

The public realm (Öffentlichkeit) set up for effective legitimation, has above all the function of directing attention to topical areas-that is, of pushing other themes, problems and arguments below the threshold of attention-and, thereby, of withholding them from opinion-formation.

Ideally in the bourgeois public sphere, only argumentation effectively tests the generalizability of interests. However, as the "liberal" model of the public sphere becomes both an object of the profit-maximizing process as well as an object of manipulation by privileged groups, Habermas comes to see only the practice of class struggle as redeeming the telos of the public sphere. In such class struggle Habermas perceives the conscious intention-however counterfactual-of a discursively grounded consensus of participants attained through argumentation.

Habermas' concept of 'social welfare state mass democracy"-which includes Offe's selection and exclusion mechanisms-allows him to discover a new basis for the bourgeois public sphere, albeit an altered one. The bourgeois public sphere then is understood as having undergone

a rational reorganization of social and political power under the mutual control of rival organizations committed to the public sphere in their internal structure as well as in their relations with the state and (with) each other (Knödler-Bunte:54).
Habermas' concept of "social welfare state mass democracy" is one of self-regulation through the public sphere. Like burgerliche Gesellschaft and its organizing Öffentlichkeit principle, the late capitalist Welfare State bases its legitimacy on the unbiased opportunity for all classes to utilize the state services and to benefit from its regulatory acts of intervention.

Habermas asserts that the generative intervention of administrative power is now both a constitutive moment of capitalist development and the immanent potential for the radicalization of consciousness. In the emergent corporatism that is advanced capitalist society, he sees the immanent potential for the unmasking of fundamental contradictions of capitalist production transformed into a crisis of legitimation, and for the reactivation of the public through possible discursive testings and the projection of counterfactual claims. Thus, in the past decade or so Habermas' concern turned to the "protest potential" posed by the protest of students, scientist and intellectuals.

Some of Habermas' own students-Claus Offe, Bernard Willms, Oskar Negt and Alexander Kluge-argue that the "social welfare state mass democracy" model posed by Habermas is only maintainable, as the liberal model was, at the cost of concealing the fundamental contradictions of capitalist production and transforming them into crises of legitimation.

Negt and Kluge expand Habermas' conception of the public sphere beyond its bourgeois content to include the class basis in which experience is constituted. They do so in order to discover the foundation and principle of development for a constituting class consciousness that could potentially oppose the organized interest. of the bourgeois public sphere. The stress is on the need for a theory of "organization" to be built into the dialectic of distorted interaction and unrepressed interaction that Habermas develops. And the public sphere is viewed in terms of repressed dialogue: the hegemony of a structure of dominancy to be exploded by dialectical thought and its teleological reconstructions and negations.

Negt and Kluge seek to point up the difference between the ideal of the bourgeois public sphere-the basis for its historical claim to legitimacy-and the actual process by which the bourgeois 
public sphere became established as an instrument of class determination. The concept of the public sphere need not be understood as merely this or that institutionalized manifestation or as one oriented essentially towards the interests in the maximization of profit. It might refer or point the way to a horizon of social experience which enables some counter-interpretations of social reality, some alternate constituting of that reality.

Negt and Kluge expand the concept of "organization" from its traditional denotation of the "combination" of human beings (groups, voluntary associations, political parties, trade unions) in order to make possible the active and mediating capacity of a constituting practical reasoning: one that formulates new interpretations of social reality beyond bourgeois institutions, new forms of public spheres. The concern is with the "organizing functions of cultural objectifications and forms of communication" in which experiences are molded, e.g., cultural assumptions, normative attitudes, collective prejudices, values (Knödler-Bunte:51-54).

The bibliography that follows presents the scope of this "second generation" of the Frankfurt School as well as links it to the related theoretical advances in both analytical philosophy and the sociology of meaning.

\section{BIBLIOGRAPHY}

Abendroth, Wolfgang

1955 "Zum Begriff des demokratischen und sozialen Rechtstaats im Grundgesetz der Bundesrepublik Deutschland" in Sultan and Abendroth, Bürokratischer Verwaltungsstaat und soziale Demokratie. (Frankfurt).

1967 Antagonistische Gesellschaft und politische Demokratie. (Neuwied).

[NOTE: The influence of Abendroth, a Marburg political scientist and legal scholar on Habermas' political thinking is great...great enough .. that the latter dedicated Strukturwandel der Öfentlichkeit to Abendroth "in Dankbarkeit".]
Adorno, Theodor W.

1951 Minima Moralia, Reflexionen aus dem Beschädigten Leben. (Frankfurt a.M.). Translated as Minima Moralia: Reflexions from Damaged Life, by E.F.N. Jephcott, (London, 1974).

1962 "Soziologie und empirische Forschung", in Max Horkheime and Theodor W. Adorno, Sociologica II. (Frankfurt, a.M.: Europä ische Verlaganstalt), pp. 205-202.

1959 "Contemporary German Sociology", translated by Norman Birnbaum in Transactions of the Fourth World Congress of Sociology, Vol. 1, (Washington, D.C.).

1967 Prisms, translated by S. and S. Weber, (London).

1970 Gesammelte Schriften, 23 volumes, ed. Rolf Tiedemann, (Frankfurt a.M.).

1970 Aufsätze zur Gessellschaftstheorie und Methodologie. (Frankfurt a.M.).

1973 Negative Dialectics. translated by E.B. Ashton, (New York)

1973 The Jargon of Authenticity. translated by K. Tarnowski and F. Will; introduction by Trent Schroyer, (Evanston, Ill.).

Adorno, Theodor W., ed.

1964 Spätkapitalismus oder Industrie-gesellschaft? Verhandlungen des 16. Deutschen Soziologentages. (Stuttgart).

Adorno, Theodor W. and Albert, Hans, et al

1976 The Positivist Dispute in German Sociology. translated by by Glyn Adey and David Frisby, (New York).

Anscombe, G.E.M.

1957 Intention. (Oxford).

Apel, Karl Otto

1955 “'Das Verstehen (eine Problemgeschicte als Begriffsgeschicte)", Archiv für Begriffsgeschicte. Vol. I.

1957 Analytic Philosophy of Language and the Geisteswissenschaft. (Dordrecht).

1959 "Sprache und Wahrheit", Philosophische Rundschau. No. 7, pp. $161 \mathrm{ff}$.

1962 "Arnold Gehlen's Philosophie der Institutionen", Philosophische Rundschaun Beiheft 10, (Tübingen).

1968 "Szientifik, Hermeneutik, Ideologie Kritik: Entwurf eine Wissenschaftslehre in erkenntnis-anthropologischer Sicht", Man and the World. 1, pp. 37-63.

1970 "Wissenschaft als Emanzipation?-Eine Kritische Würdigung der Wissenschaftskonzeption der 'Kritischen Theorie'", Zeitschrift für Allgemeine Wissenschaftstheorie. No. 1. Apel,

Apel, Karl Otto, et al. (ed) Hermeneutik und Ideologiekritik. (Frankfurt a.M.). 
Apel, Karl Otto

1972 "Communication and the Foundations of the Humanities", Acta Sociologica. Vol. 15 \& Man and the World. 5.

1973 "Das Apriori der Kommikationsgemeinschaft und die Ethik" in K.O. Apel, ed., Transformation der Philosophie. 2 volumes (Frankfurt a.M.), translated as "Apriori of Communication" in Man and the World. 6 (1973).

1973 "Von Kant zu Peirce. Die Semiotische Transformation der Transzendentalen' Logic" in Apel, Tranfermation der Philosophie. Vol. 2, op. cit.

1974 "Das Problem der philosiphischen Letzbegreindung im Lichte einer transzendentalen Sprachpragmatik (Versuch einer Metakritik des 'Kritischen Rationalismus')" in B. Kanitscheider, ed., Festschrift für Gerhard Frey. (Frankfurt a.M.).

Apel, Karl Otto, ed.

Baier, $\mathrm{H}$

1976 Sprachpragmatik und Philosophie. (Frankfurt a.M.).

1966 "Soziologie und Geschicte: Überlegungen zur Kontroverse zwischen dialektischer und neopositivistischer Soziologie", Archiv für Rechts und Sozial Philosophie. Vol. 52.

1969 "Soziale Technologie oder soziale Emanzipation? Zum Streit zwischen Positivisten und Dialektiken über die Aufgabe der Soziologie" in B. Schäfers, ed., Thesen zur Kritik der Soziologie. (Frankfurt a.M.).

Benjamin, Walter

1970 Illuminations. translated by Harry Zohn, ed., Hannah Arenht, (New York, first published 1936).

Bernstein, Richard J.

1976 The Restructuring of Social and Political Theory. (New York).

Betti, E.E.

1962 Die Hermeneutik als allgemeine Methodik der Geisteswissenschaften. (Tübingen).

Blum, A.F., Foss, D., McHugh, P, and Raffel, S

1974 On The Beginning of Social Inquiry. (London: Routledge \& Kegan Paul).

Blum, A.F. and McHugh, P.

1971 "The Social Ascription of Motive", American Sociological Review. Vol. XXXV, n.1 (Feb.) pp. 98-108.

Bubner, Rüdiger

1969 "Was ist Kritische Theorie?", Philosophische Rundschau. Nos. 3-4, pp. 213-249.
1971 "Was ist Kritische Theorie?" in K.O. Apel, et al. Hermeneutik und Ideologie Kritike op. cit.

1973 Dialektik und Wissenschaft. (Frankfurt a.M.).

Bubner, Rüdiger, K.Cramer und R. Wiehl, eds.

1970 Hermeneutik und Dialektik 2 Volumes (Tübingen). Buck-Morss, Susan

1977 The Origin of Negative Dialectics: Theodor W. Adomo,

Cavell, S. Walter Benjamin and the Frankfurt Institute. (New York).

1968 Must we mean what we say? (New York: Scribners).

"The Availability of Wittgenstein's Later Philosophy", Philosophical Review. Vol. 71, pp. 67-93.

Cicourel, Aaron

1973 Cognitive Sociology. (N.Y.: Free Press).

1964 Method and Measurement in Sociology. (N.Y.: Free Press).

1975 Power, Rule and Domination. (London).

Dallmayr, Fred R.

1972 "Critical Theory Criticized: Habermas' Knowledge \& Human Interests and its Aftermath." Philosophy of the Social Sciences 2 .

Dallymayr, Fred

1976 “Marxism \& Truth”, Telos. N. 29, (Fall) pp. 130-159.

1972 "Reason \& Emancipation: Notes on Habermas", Man \& the World 5.

Duncan, Hugh D.

1962 Communication and the Social Order. (New York: Oxford).

1958 Symbols in Society. (New York: Oxford).

Fishman, Joshua A., ed.

1971 Advances in the Sociology of Language. (The Hague: Mouton).

Frankel, Boris

1971 "Habermas talking: An Interview", Theory \& Society. Vol. I, n. 2.

Frisby, David

1974 "The Frankfurt School: A critical theory of society" in J. Rex, ed., Approaches to Sociology. (London: Routledge \& Kegan Paul).

Gadamer, Hans Georg

1967 Das Problem der Sprache. (Munich).

1970 Hermeneutik und Dialektic. (Tübingen).

1971 Hermeneutik und Ideologiekritik. (Frankfurt).

1976 Truth \& Method. translated by Garrett Barden \& John Cumming from the second (1965) edition. (N.Y.: Seabury). 
Mid-American Review of Sociology

Giddens, Anthony

1976 New Rules of Sociological Method: A Positive Critique of Interpretive Sociologies. (New York: Basic Books).

Gottlieb, Gidon

1968 The Logic of Rules. (London)

1974 "The Metaphoricality of Marxism \& the Context-freeing Grammar of Socialism", Theory \& Society. V. I, n. 4.

Habermas, Jürgen [with L. Friedeburg, C., Oehler, F. Weltz].

1961 Student and Politik. (Frankfurt a.M.)

1962 Strukturwandel der Öffentlickkeit. (Neuwied: Luch terhand).

1963 Theorie und Praxis. (Neuwied: Luchterhand)

1973 Theory and Practice.

1974 "The Public Sphere: An Encyclopedia Article (1964)", New German Critique. I:3 (Fall), pp. 45-55.

1968 Erkenntnis und Interesse. (Frankfurt:Suhrkamp).

1971 Knowledge and Human Interests. (Boston: Beacon), trans. J.J. Shepiro.

Habermas, Jürgen, ed.

1968 Antworten auf Herbert Marcuse. (Frankfurt a.M.).

1973 "On Systematically Distorted Communication", Inquiry. 13 pp. 205-218.

1970 Zur Logik der Sozialwissenschaften. (Frankfurt: Suhrkamp).

1970 Towards a Rational Society. (Boston: Beacon) translated by J.J. Shapiro.

1970 "Towards a Theory of Communicative Competence", Recent Sociology. No. 2, ed., H.P. Dreitzel.

1970 Protesbewegung und Hochschulreform. (Frankfurt a.M.).

1971 "Der Universalitätsanspruch der Hermeneutik", in Hermeneutik und Ideologiekritik. (Frankfurt am Main: Suhrkamp Verlag).

1971 "Exkuns über Gfundannahmen des Historischen Materialismus". in. J. .Habermas and Nikles Luhmann. Theorie der Gesellschaft oder Sozial technologie? (Frankfurt: Suhrkamp Verlag).

1974 "Wozu noch Philosophie?"' in Philosophisch-Politische Profile. (Frankfurt '71) translated in, Social Research Vol. 40.

1971 "Vorbereitende Bemerkungen zu einer Theorie der Kommunikativen Kompetenz" in Habermas and Luhmann op. cit.

1973 "Wahrheitstheorien" in Wirklichkeit und Reflexion: fest schrift für Walter Schulz. ed., H. Fahrenbach (Pfullingen: Neske).

\section{Frankfurt School}

1973 "What does a crisis mean today? Legitimation Problems in Late Capitalism", Social Research. Vol.40, n. 4 (Winter) pp. 643-667.

1973 Legitimationsprobleme im Spätkapitalismus. (Frankfurt: Suhrkamp).

1975 Legitimation Crises. translated by T. McCarthy (Boston: Beacon).

1973 “On Social Identity", Telos. 19, pp. 90-103.

1973 "A Postscript to Knowledge and Human Interests", Philosophy of Social Science. 3.

1973 Kultur und Kritik. (Frankfurt).

1975 Der Spiegel. Feb. 24.

1975 "Towards a Reconstruction of Historical Materialism", Theory and Society. 2, n. 3 (Fall), pp. 287-300

1975 Zur Entwicklung der Interaktienskompetenz. (Frankfurt: Gesellschaft zur Förderung der Wissenschaft).

1975 "Moral Development and Ego Identity", Telos. 2, pp. 41-55.

1976 "Legitimationsprobleme im modernen Statt", Merkur. 30 (January), pp. 37-56.

1976 "A Positively Bisected Rationalism" in Adorno, et al. The Positivist Disspute. op. cit. pp. 198-225.

1976 "The Analytic Theory of Science and Dialectics: A Postscript to the Controversy between Popper and Adorno" in Theodor W. Adorno, et al. The Positivist Dispute in German Sociology. translated by G. Adey and D. Frisby (Harper \& Row), pp. 131-162.

1976 "Some Distinctions in Universal Pragmatics: A Working Paper", Theory and Society. V. 3, n. 2 (Summer), pp. 155-167, translated by P. Pekelhacing and C. Visco.

1976 "Was Heisst Universal Pragmatik?" in K.O. Apel, ed., Sprachpragmatik und Philosophie. (Frankfurt a.M: Suhrkamp), pp. 174-273.

1977 "'Hannah Arendt's Communications Concept of Power", Social Research. XLIV, n. 1, pp. 3-24.

Henle, Paul

1968 Language, Thought and Culture. (Ann Arbor).

Hohendal, Peter and Jürgen Habermas

1974 "The Public Sphere", New German Critique. 3 (Fall) pp. 45-55.

Horkheimer, Max

1947 The Eclipse of Reason. (Oxford).

1967 Zur Kritik der instrumentellen Vernunft. (Frankfurt a.M.).

1972 Critical Theory. translated by M.J. O'Connell, (N.Y. Herder \& Herder). 
Horkheimer, Max and Adorno, Theodor W.

1972 Dialectic of Enlightenment. translated by J. Cumming, (New York).

Howard, Dick

1974 "A Politics in Search of the Political", Theory and Society.

Ihde, Don

1970 Hermeneutic Phenomenology. (Evanston).

Jay, Martin

1973 The Dialectical Imagination: A History of the Frankfurt School and the Institute of Social Research, 1923-50. (Boston).

Jakobson, Roman

1965 Relations entre la science du language et les autre sciences in Essais de linguistic générale. II, (Paris).

Keane, John

1975 "On Tools and Language: Habermas on Work and Interaction", New German Critique. 6 (Fall), pp. 82-100.

Knödler-Bunte, Eberhard

1975 "The Proletarian Public Sphere and Political Organizatise: An Analysis of Oskar Negt and Alexander Kluge's the Public Sphere and Experience" in New German Critique 4 (Winter) pp. 50-75.

Kuhn, Hans-Martin

1974 Der Lange Marsch in den Faschismus. (Frankfurt).

Lowenthal, Richard

1976 "Social Transformation and Democratic Legitimacy", Social Research 43, n. 2 (Summer) pp. 246-275.

Luhmann, Niklas

1971 "Systemstheoretische, Argumentationen: Eine Entgegnung auf Jürgen Habermas" in J. Habermas and N. Luhmann, Theorie der Gesellschaft oder Sozialtechnologie. (Frankfurt a.M.), pp. $241-405$.

McCarthy, T.A.

1973 "A Theory of Communicative Competence" in Philosophy of the Social Sciences 3, pp. 136-56.

McHugh, P.

1968 Defining the Situation. (Indianapolis: Bobbs-Merrill).

Mischel, Theodore

1969 Human Action. (New York).

1974 Understanding Other Persons. (Oxford).

Mueller, Claus

1973 The Politics of Communication. (N.Y.: Oxford University Press).
Negt, Oskar

1969 "Introduction", A. Deborin and N. Bukharin. Kontroversen über dialekhtichen und mechanistischen Materialismus. (Frankfurt).

1970 Aktualitat und Folgen Hegels. (Frankfurt a.M.).

1971 "Revolution und Geschicte: Eine Kontroverse mit Jürgen Habermas", Politik als Protest. (Frankfurt a.M.).

Negt, Oskar and Kluge, Alexander

1972 Offentlichkeit und Ekfahrung: Zur organizationsanalyse von bürgerlicher und proletarischer Offentlichkeit. (Frankfurt: Suhrkamp)

Negt, Oskar

1974 "Rosa Luxemburg: Zur Materialistischen Dialektik von spontaneität und organization" in C. Pozolli, ed., Rosa Luxemburg oder Die Bestimmung des Sozialismus (Frankfurt a.M.).

1974 "Don't Go By Numbers. Organize According to Interests! Current Questions of Organization", New German Critique 1, n. 1 (Winter)

1975-76" "Theory, Empiricism and Class Struggle: On the Problem of Constitution in Karl Korsch", translated by R. Morrow in Telos. 26 (Winter), pp. 120-142.

O'Connor, James

1973 The Fiscal Crisis of the State. (New York).

O'Neill, John

1972 "Can Phenomenology be Critical?", Sociology as a Skin Trade. (New York: Harper Torchbooks).

Offe, Claus

1969 "Politische Hereschaft und Klassen Strukturen" in G. Kress, L.D. Senghass, eds., Politikwissenschaft. (Frankfurt).

1972 "Political Authority and Class Structure-An Analysis of Late Capitalist Societies", International Journal of Sociology. (Spring) pp. 73-108.

1970 Leistangsprinzip und Industrielle Arbeit. (Frankfurt).

1973 Strukturprobleme des Kapitalischen Staates. (Frankfurt am Main: Shurkamp Verlag).

1974 "Structural Problems of the Capitalist State", German Political Studies I, pp. 31-57.

Offe, Claus and Narr, Wolf Dieter

1973 Wohlfahrtsstaat und Massenloyalität. (Koln). Offe, Claus

1973 "Krise und Krisen Management" in M. Jänicke, ed. Herrschaft und Krise. (Opladen).

1973-74"The Abolition of Market Control and the Problem of Legitimacy," Working Papers on the Kapitalistate 1 (May) pp. 109-116, 2 (Dec-Jan) pp. 73-75. 
1975 "The Theory of the Capitalist State and the Problem of Policy-Formation" in L. Lindberg, R. Alford, C. Crouch, C. Offe, eds. Stress and Contradiction in Modern Capitalism. (Lexington, Mass). pp. 125-144.

1975 Bederfungsreform. (Frankfurt a.M.).

1975 "Further Comments on Müller and Neusüss", Telos. 25 (Fall).

Offe, Claus and Ronge Volker

1975 "Theses on the theory of the state", New German Critique. n. 6 (Fall), pp. 139-147.

Paci, Enzo

1972 The Function of the Sciences and the Meaning of Man. Palmer, Richard

1969 Hermeneutics. (Evanston).

Piccone, Paul

1971 "Phenomenological Marxism", Telos 9.

Pilot, Harald

1976 "Jürgen Habermas' Empirically Falsifiable Philosophy of History" in T.W. Adrno, et al. The Positivist Dispute in German Sociology. (Harper \& Row) pp. 258-282, Trans. 6, Adey \& Frisby.

Psathas, George

1973 Phenomenological Sociology. (New York).

Rawls, John

1964 “Two Concepts of Rules", Philosphical Review LXIV.

Richert, $\mathrm{H}$.

1924 Kulturwissenschaft und Naturwissenschaft 6th \& 7th Editions (Tübingen).

1962 Science and History. translated by G. Reisman (Princeton).

Ricoeur

1971 "The Model of the Text: Meaningful Action Considered as a Text", Social Research XXXXII.

Riedel, M., ed.

1972 Rehabilitierung der praktischen Philosophie. (Freiberg; Vol. 1,1972; Vol. 2, 1974).

Sandywell, Barry, et al.

1975 Problems of Reflexivity and Dialectics in Sociological Inquiry. (London).

Sardei-Berman, Sabine, Christiansen, Jens and Dohse, Knuth

1973-74 "Class Domination and the Political System: A Critical Interpretation of the Recent Contribution of Claus Offe" in Working Papers in the Kapitalstate 2 (Dec. Jan.), pp. 61-70.
Saussure, Ferdinand de

1967 Cours de linguistique générale, edition critique de R. Engler (Wiesbaden).

Schmidt, Alfred

1962 Zur Frage der Dialektik in Nietzches Erkenntnistheoris. (Munich).

1965 Zur Verhaltnis von Geschichte und Natur in Dialektischen Materialismus. (Mu'nich).

1965 Existentialism und Marxismus. (Frankfurt a.M.)

1967 Über Geschichte und Geschechtsscreibung in der Materialistischen Dialektik" in Folgen giner Theorie, Essays über 'Das Kapital' von Karl Marx. (Frankfurt a.M.).

1968 "Zum Erkenntinshegriff der Kritik der politischen 'Okanomie' ", in Kritik der Politischen Ökonomie heute 100 Jahr, 'Kapital', eds., W. Euchner and A Schmidt (Frankfurt).

1969 Kunst und Politik. (Karlsruhe).

1969 "Der strukturalistische Angriff auf die Geschichte", Beiträge zur marxistischen Erkenntnistheorie. ed., A. Schmid (Frankfurt a.M.).

1970 Die "Zeitschrift für Sozialforschung": Geschichte und genenwärtige Bedeutung. (Munich).

1971 Der Begriff der Natur in der Lehre von Marx [. . . mit einem Postscriptum...]. (Frankfurt a.M.), translated by Ben Fowkers as The Concept of Nature in Marx. (London, 1971).

1971 Geschichte und Struktur: Fragen einer Marxistischen Historik. (Munich).

1971 Emanzipatorische Sinnlichkeit: Ludwig Fuerbach's Anthrolologischer Materialismiss. (Munich).

1973 (1) "Statt eines vorwarts: Geschichte als verändernde Praxis", pp. 739; and (2) "Existential Ontologie unde historischer Materialismus bei Herbert Marcuse," Pp. 111-142 in H. Marcuse and A. Schmidt, Schroyer, Trent Existentialistische Marx-Interpretation. (Frankfurt a.M.)

1973 The Critique of Domination. (N.Y.: George Brazilla).

1975 "The Re-Politicization of the Relations of Production: An Interpretation of Jürgen Habermas' Analytic Theory of Late Capitalist Development", New German Critique n. 5 (Spring).

Scott, Marive and Lyman, Stanford

1968 "Accounts", American Sociological Review XXXIII (Dec) pp. 46-62. 
Mid-American Review of Sociology

Searle, John

1969 Speech Acts. (Cambridge UK).

Shapiro, Jeremy

1976 "Reply to Miller's Review of Habermas, Legitimation Crisis", in Telos 27.

Schwayder, O.S.

1965 The Stratification of Behavior. (London, Routledge and Kegan Paul).

Taylor, Charles

1971 "Interpretation and the Science of Man", Review of Metaphysics XXV, n. 3 pp. 145 .

Toulmin, Stephen

1964 The Uses of Argument. (Cambridge).

1972 Human Understanding Vol. I (Princeton).

vonWright, Georg Henrik

1963 Norm and Action. (London).

1971 Explanation and Understanding. (Ithaca).

Weber, Max

1968 Economy and Society: An Outline of Interpretive Sociology. edited and with an introduction by Gunther Roth and C. Wittich (New York).

Wellmer, Albrecht

1970 "Communication and Emancipation: Reflections on the Linguistic Turn "in Critical Theory" (ed. P. Bryns; C. Evans. and D. Howard), in Stony Brook Studies in Philosphy.

1971 Critical Theory of Society. (New York: Herder and Herder) translated by J. Commings.

Willms, B.

1966 "Theorie, Kritik und Dialektik", Soziale Welt Vol. 17 reprinted in Über Theodor W. Adorno. (Frankfurt a.M.).

1973 Kritik und Politik: Habermas oder das politische Defizit der "Kritischen Theorie". (Frankfurt a.M.).

Winch, Peter

1958 The Idea of a Social Science and its Relation to Philosophy. (London).

1972 Ethics and Action. (London)

Windelband, W.

1924 Gerschicte und Naturwissenschaft" in Präludien 2 Volumes (Tübingen).

Winters, Lawrence E.

1973-74 "Habermas' theory of Truth and its Centrality in his Critical Project", Graduate Faculty Philosophical Journal. (New School for Social Research), V. 3 n. 11 (Fall Winter).
Frankfurt School

Wit tgenstein, Ludwig

1953 Philosphical Investigations. translated by G.E.M. Anscombe (New York).

Zaner, Richard $\mathrm{M}$.

1961 "Theory of Intersubjectivity: Alfred Schutz", Social Research XXVII, pp. 71-93.

Ziman, John

1963 Public Knowledge: The Social Dimension of Science. (Cambridge). 